\title{
РОЗРАХУНОК РАЦІОНАЛЬНИХ КОНСТРУКТИВНО- ТЕХНОЛОГІЧНИХ ПАРАМЕТРІВ СОРТУВАЛЬНИХ ГІРОК НА ОСНОВІ СИСТЕМНОГО ПІДХОДУ
}

\begin{abstract}
Постановка проблеми у загальному вигляді, іiі зв'язок 3 важливими науковими та практичними завданнями. На даний момент сортувальні гірки є одним 3 основних споживачів паливноенергетичних i виробничих ресурсів на транспорті і відповідальною ланкою за скорочення простоїв вагонів на станціях. Використання вказаних ресурсів суттєво підвищують такі фактори, як недосконалість існуючої технології регулювання швидкості скочування відчепів і технічних засобів, що забезпечують це регулювання, відсутність комплексної автоматизації процесу розформування составів на залізничних станціях України, зокрема систем підтримки прийняття рішень оперативним персоналом, застосування традиційної конструкції поздовжнього профілю, наявність у ряді випадків надлишкової висоти гірок та низький рівень урахування параметрів метеорологічних умов у процесі експлуатації сортувальних пристроїв. Слід також зазначити, що випадковий характер вказаних параметрів, а також системний підхід до експлуатації та розрахунку сортувальних гірок не в повній мірі враховуються на стадії їх проектування або реконструкції, що відповідним чином відображається на якості проектів.

Таким чином, подальший розвиток теорії експлуатації та методів розрахунку параметрів сортувальних гірок на основі системного підходу 3 урахуванням
\end{abstract}

випадкового характеру чинників, що впливають на швидкість скочування відчепів 3 гірки, являє собою актуальну науково-прикладну проблему.

Аналіз останніх досліджень i публікацій. Створенням і розвитком теорії експлуатації, методів розрахунку та оцінки конструктивно-технологічних параметрів сортувальних гірок займалися такі вчені та практики, як: Л.В. Абуладзе, С.В. Архангельський, К.С. Ахвердієв, М.М. Бабаєв, П.В. Бартенєв, І.В. Берестов, С.А. Бессоненко, В.І. Бобровський, М.П. Божко, В.Я. Болотний, Т.В. Бутько, Є.А. Гібшман, А.Н. Гуда, Ю.Т. Гурічев, М.І. Данько, М.Г. Дашков, О.М. Долаберідзе, Ю.І. Єфіменко, І.В. Жуковицький, В.М. Іванченко, В.К. Івашкевич, А.М. Карпов, Д.М. Козаченко, А.М. Козлов, О.М. Лебединська, М.Н. Луговцов, І.М. Малишев, С.С. Мацкель, Ю.А. Муха, Є.В. Нагорний, В.Я. Негрей, В.Д. Нікітін, В.М. Образцов, В.С. Павлов, А.С. Писанко, М.В. Правдін, М.О. Рогинський, В.М. Рудановський, I.Є. Савченко, I.І. Страковський, Л.Б. Тішков, М.М. Уздін, М.І. Федотов, О.М. Шабельніков, В.П. Шейкін, В.І. Шелухін, О.Г. Шепілова, А.П. Шипулін та інші [1-15].

Аналіз відомих теоретичних підходів до експлуатації та розрахунку параметрів сортувальних гірок довів, що:

1) не в повній мірі вирішено проблеми якісного регулювання швидкості скочування відчепів і вибору раціональної конструкції поздовжнього профілю; 
2) недостатньо уваги приділено проблемі ресурсозбереження при гальмуванні відчепів вагонними уповільнювачами i формуванні структур гіркових горловин;

3) не в повній мірі вивчено можливості i ефективність систем підтримки прийняття рішень для гіркових операторів.

Основним недоліком теорії експлуатації та методів розрахунку параметрів сортувальних гірок $\epsilon$ відсутність наукових підходів, що одночасно визначають i стратегію функціонування сортувального пристрою на період життєвого циклу, i його раціональні конструктивно-технологічні параметри. Тобто комплексно рішення вказаних задач не розглядалось.

Мета дослідження. Метою даних досліджень $\epsilon$ забезпечення заощадження паливно-енергетичних, виробничих i перевізних ресурсів при виконанні операцій гіркового технологічного процесу шляхом удосконалення наукового підходу до розрахунку раціональних конструктивнотехнологічних параметрів сортувальних гірок.

Основна частина. Підвищення ефективності сортувального процесу на залізничних станціях України може бути забезпечено шляхом удосконалення конструкції i технології роботи сортувальних гірок. Оскільки конструкція поздовжнього профілю і число вагонних уповільнювачів залежать від заданої швидкості розпуску составів, визначення раціональних конструктивно-технологічних параметрів сортувальної гірки слід здійснювати за умовою мінімізації видів витрат системи 3 наростаючим підсумком $(E)$ за період життєвого циклу $\left(t_{ж и}\right)$

$$
E=\int_{0}^{t_{\text {жи }}} E\left(V_{p}, V_{\text {вих1 }}, V_{\text {вих } 2}, t\right) d t \rightarrow \min ,
$$

де $E\left(V_{p}, V_{\text {вих } 1}, V_{\text {вих } 2}, t\right) \quad-\quad$ миттєві експлуатаційні витрати системи 3 наростаючим підсумком, млн грн;

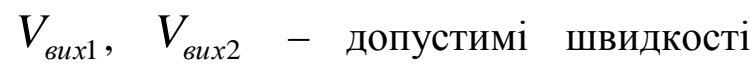
виходу відчепів відповідно 3 I гальмових позицій, м/с.

Мінімізація цільової функції здійснюється при таких обмеженняхнерівностях

$$
\left\{\begin{array}{l}
0,8 \leq V_{p} \leq V_{p}^{\max } \\
V_{\text {вux } 1}^{P B} \leq V_{\text {вих1 } 1} \leq V_{\text {вux } 1}^{X Б} \\
V_{\text {вux } 2} \leq V_{\text {вux } 2}^{X Б},
\end{array}\right.
$$

де $V_{p}^{\max } \quad-\quad$ максимально можлива швидкість розпуску составів, м/с;

$$
V_{\text {вих } 1}^{P Б}, V_{\text {вих1 }}^{\text {ХБ }} \text { - швидкість виходу } 3 \text { I }
$$

гальмової позиції відповідно дуже поганого (ДП) і хорошого бігунів (ХБ) при вільному скочуванні, м/с;

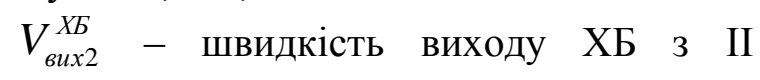
гальмової позиції при вільному скочуванні, $\mathrm{M} / \mathrm{c}$.

Швидкість розпуску составів i режими гальмування відчепів, які визначаються швидкостями $V_{\text {виx } 1}$ i $V_{\text {виx2 }}$, при прийнятих числі i типі гіркових локомотивів та вагонних уповільнювачів на спускній частині i підгіркових коліях впливають на такі показники, як витрати електроенергії на регулювання швидкості скочування відчепів $G_{\text {eл }}$, число ушкоджених вагонів $n_{\text {уик }}$ і додатковий простій составів у парку приймання в очікуванні розформування $t_{o ч}^{n n}$. Крім того, від швидкості розпуску составів залежать витрати палива на насув і розформування составів $G_{n}$. Вказані показники розраховуються 3 використанням моделі функціонування сортувальної гірки, яка наведена далі. 
У реальному масштабі часу швидкість виконання маневровим локомотивом окремих операцій гіркового технологічного процесу (заїзду, перестановки, насуву, розпуску і осаджування) $\left(V_{л}(t)\right)$ можна вважати єдиним керованим вхідним впливом на систему „Сортувальна гірка”. Це пов'язано з тим, що вказана швидкість встановлюється на підставі діючих нормативних документів або спеціальних розрахунків. Позначимо множину впливів, що здійснюють цілеспрямовану зміну стану системи „Сортувальна гірка”, через $U(t)$.

До множини некерованих вхідних впливів $V(t)$ належать параметри, що відображають поточний стан метеорологічних умов (температура зовнішнього повітря $\left(t^{o}(t)\right)$, швидкість $(V s(t))$ та напрямок $(\beta(t)$ вітру), та інтенсивність вхідного вагонопотоку у момент часу $t(\lambda(t))$.

Стан системи „Сортувальна гірка” у момент часу $t$ можна записати у такому вигляді:

$$
Q(t)=F^{o}\left(t, Q_{o}, Z(t), P(t), U(t), V(t)\right),
$$

де $F^{o}$ - оператор стану системи;

$Q_{o}$ - початковий стан системи;

$Z(t)$ - характеристики системи, які залежать від множини вхідних впливів $U(t) \cup V(t)$ на систему;

$P(t)$ - множина параметрів керування, які можуть змінюватись у процесі функціонування системи та забезпечувати підвищення її якості.

Початковим станом системи $\epsilon$ множина таких параметрів: число гіркових локомотивів $\left(N_{\text {гл }}\right)$, крутизна елементів поздовжнього профілю насувної частини гірки $\left(I_{н ч}\right), \quad$ крутизна елементів поздовжнього профілю спускної частини гірки $\left(I_{c y}\right), \quad$ число вагонних уповільнювачів, що розташовані на спускній частині $\left(N_{c y}\right)$, число вагонних уповільнювачів, що розташовані на сортувальних коліях $\left(N_{c \kappa}\right)$, потужність $\left(P_{\text {лок }}\right)$ i довжина $\left(l_{\text {лок }}\right)$ гіркового локомотива, число стрілочних переводів $\left(N_{c m p}\right)$ і кривих дільниць колій $\left(N_{\kappa p}\right)$, координати центрів переводів $\left(x_{u n}, y_{u n}\right) \mathrm{i}$ вершин кутів повороту $\left(x_{\varepsilon \kappa}, y_{в \kappa}\right)$, кути повороту на стрілочних переводах ( $\left.\alpha_{c m p}\right)$ та кривих дільницях колій ( $\left.\alpha_{\kappa p}\right)$, радіуси перевідних кривих стрілочних переводів $\left(R_{c m p}\right)$ і кривих дільниць колій $\left(R_{\kappa p}\right)$, радіуси вертикальних кривих $\left(R_{b}\right)$, число колій у парку приймання $\left(m_{\kappa}\right)$, годинні витрати палива гірковим локомотивом $\left(q_{\text {год }}\right)$, витрати електроенергії на одне спрацювання вагонного уповільнювача $\left(q_{\text {eл }}\right)$, вартість дизельного палива $\left(e_{n}\right) \mathrm{i}$ електроенергії $\left(e_{e л}\right)$, вартість вагонних уповільнювачів $\left(K_{y n}\right)$ i гіркових локомотивів $\left(K_{\text {лок }}\right), \quad$ тарифні ставки робітників, що обслуговують вагонні уповільнювачі $\left(C_{m c}^{y n}\right)$ і гіркові локомотиви $\left(C_{m c}^{\text {лок }}\right)$, нормативні працевитрати на технічне обслуговування вагонних уповільнювачів $\left(T_{m o}^{y n}\right)$ i $\quad$ гіркових

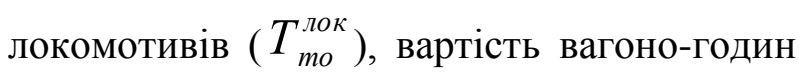
простою $\left(e_{\text {ваг-год }}\right)$, об'єм $\left(V_{3}\right)$ і вартість проведення $\left(e_{3}\right)$ земляних робіт, вартість систем автоматизації ( $\left.C_{a в m}\right)$.

Основною характеристикою системи, що залежить від множини вхідних впливів $U(t)$ і $V(t), \quad \epsilon$ рівень годинного завантаження гірки у момент часу $t$ 
$\left(\rho_{2}(t)\right)$. До параметра керування слід віднести миттєву питому роботу гальмових сил при гальмуванні відчепів на спускній частині і підгіркових коліях $\left(h_{2}(t)\right)$.

Виходом системи „Сортувальна гірка” $\epsilon$ множина параметрів

$$
Y(t)=\left(G_{n}(t), G_{\text {ел }}(t), n_{\text {уик }}(t), t_{\text {оч }}^{n n}(t)\right),
$$

де $G_{n}(t)$ - сумарні витрати палива гірковими локомотивами на насув і розпуск составів;

$G_{e л}(t)$ - сумарні витрати електроенергії на регулювання швидкості скочування відчепів; $n_{\text {ушк }}(t)$ - сумарне число ушкоджених вагонів на гірці;

$t_{o ч}^{n n}(t)$ - сумарний простій составів у парку приймання в очікуванні розформування.

Значення вихідних параметрів $Y(t) \epsilon$ координатами фазової траєкторії у фазовому просторі та залежать від вхідних впливів $U(t)$ і $V(t)$, внутрішньої характеристики системи $Z(t)$ і параметра керування $P(t)$. Таким чином, виходячи із системного підходу [16], закон функціонування системи „Сортувальна гірка” буде мати такий вигляд:

$$
Y(t)=G^{o}\left(t, Q_{o}, Z(t), P(t), U(t), V(t), S(t)\right)
$$

або

$$
Y(t)=G^{o}\left(t, Q_{o}, \rho_{2}(t), h_{2}(t), V_{\pi}(t), t^{o}(t), V_{B}(t), \beta(t), \lambda(t), S(t)\right),
$$

де $G^{o}$ - оператор виходу;

$S(t)$ - вектор структурної перебудови;

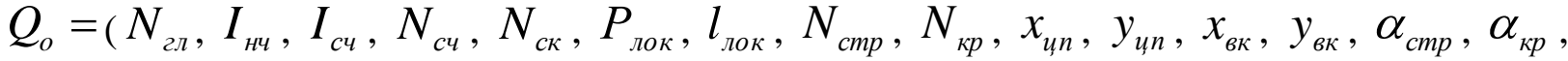
$R_{c m p}, R_{\kappa р}, R_{6}, m_{\kappa}, q_{\text {год }}, q_{\text {ел }}, e_{n}, e_{\text {ел }}, K_{y n}, K_{\text {лок }}, C_{m c}^{y n}, C_{m c}^{\text {лок }}, T_{\text {то }}^{y n}, T_{\text {то }}^{\text {лок }}, e_{\text {ваг-год }}, V_{3}$, $\left.e_{3}, C_{a b m}\right)$.

Структурною перебудовою системи може бути зміна:

1) конструкції поздовжнього профілю сортувальної гірки;

2) конструкції плану колійного розвитку сортувальної гірки;

3) числа вагонних уповільнювачів на гальмових позиціях;

4) типів гіркових локомотивів;

5) режимів регулювання швидкості скочування відчепів з гірки;

6) систем автоматизації сортувального процесу.
Структурна перебудова може відбутися внаслідок:

1) зміни розрахункових метеорологічних умов скочування відчепів з гірки;

2) зміни обсягу i структури вагонопотоку, що переробляється;

3) переоснащення гальмових позицій;

4) природного погіршення технічних характеристик гіркових локомотивів i вагонних уповільнювачів;

5) перебудови (реконструкції) передгіркової горловини; 
6) зміни вартості паливноенергетичних ресурсів;

7) зміни тарифних ставок робітників, що обслуговують гіркові локомотиви i вагонні уповільнювачі;

8) зміни нормативних працевитрат на технічне обслуговування гіркових локомотивів і вагонних уповільнювачів;
9) зміна вартості вагоно-годин простою.

Конфігурація фазового простору $\boldsymbol{\Phi}$ системи визначається 3 урахуванням обмежень на вхідний керований вплив $V_{\Omega}(t)$, некеровані вхідні впливи $t^{o}(t)$, $V \boldsymbol{B}(t), \beta(t), \lambda(t)$, характеристику системи $\rho_{2}(t)$ та параметр керування $h_{2}(t)$

$$
\begin{aligned}
& \Phi \in \mathrm{E}_{\mathrm{k}}
\end{aligned}
$$

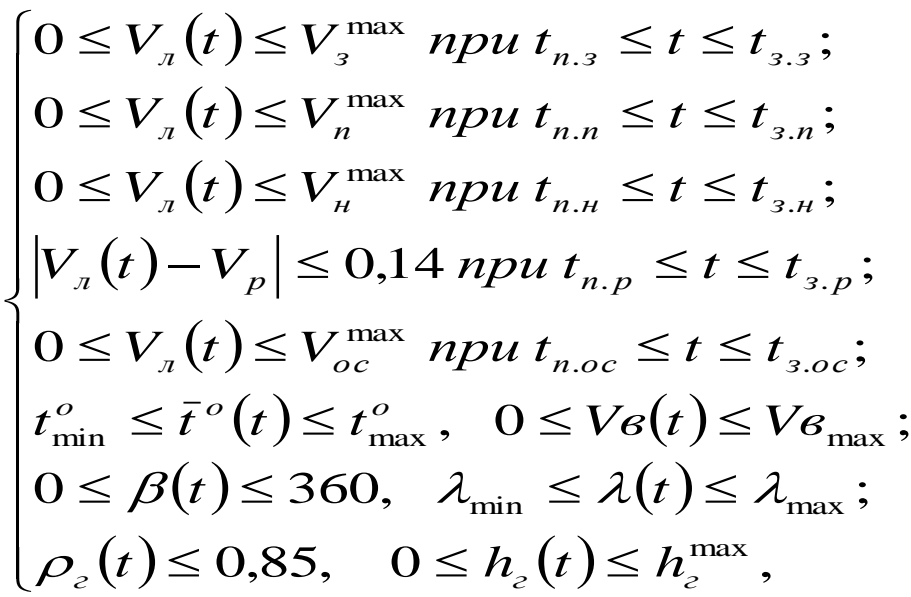

де $V_{3}^{\max }, V_{n}^{\max }, V_{H}^{\max }, V_{o c}^{\max }$ - максимальна швидкість відповідно заїзду гіркового локомотива у парк приймання, перестановки состава 3 парку приймання на витяжну колію, насуву состава на гірку та осаджування вагонів на сортувальних коліях, м/с;

$t_{n .3}, t_{3.3}, t_{n . n}, t_{3 . n}, t_{n . h}, t_{3 . H}, t_{n . p}, t_{3 . p}, t_{n . o c}, t_{3.0 c}$ - моменти часу відповідно початку i закінчення заїзду гіркового локомотива у парк приймання, перестановки состава 3 парку приймання на витяжну колію, насуву состава на гірку, розпуску состава 3 гірки та осаджування вагонів на сортувальних коліях, с;

$$
t_{\min }^{o}, t_{\max }^{o}-\text { відповідно мінімально i }
$$

максимально можлива температура зовнішнього повітря, ${ }^{\circ} \mathrm{C}$;
$V \boldsymbol{B}_{\max }$ - максимально можлива швидкість вітру, м/с;

$$
\lambda_{\min }, \lambda_{\max }-\text { відповідно мінімально } \mathrm{i}
$$
максимально можлива інтенсивність вхідного вагонопотоку, ваг/год;

$h_{2}^{\max }$ - максимально можлива питома робота гальмових сил при гальмуванні вагонів на спускній частині і підгіркових коліях, кДж/кН.

Швидкість розпуску i режими гальмування відчепів, що забезпечують мінімальні види витрат системи 3 наростаючим підсумком за період життєвого циклу, визначають стратегію іiі експлуатації. Реалізація цієї стратегії шляхом ефективного керування процесом розформування составів має наближувати функціонування системи до нормальної фазової траєкторії, що може бути представлено такою моделлю: 


$$
\begin{gathered}
\int_{0}^{t_{1}}\left|E_{p}(t)-E_{\phi}(t)\right| d t \rightarrow 0 \\
0 \leq t_{1} \leq t_{\text {жи }}
\end{gathered}
$$

де $E_{p}(t), E_{\phi}(t)$ - миттєві експлуатаційні витрати системи відповідно при іiі раціональних конструктивно-технологічних параметрах і фактичні, млн грн.

Висновки 3 дослідження $\mathbf{i}$
перспективи, подальший розвиток $\mathbf{y}$
даному напрямку. Запропонований
системний п्дхід до визначення
раціональних конструктивно-технологічних
параметрів сортувальних гірок дозволяє
отримати комплексне рішення задач
раціоналізації вказаних параметрів, визна-
чити стратегічний напрямок експлуатації
сортувальних пристроїв, у динаміці оцінити
якість конструкції і технології роботи
існуючих сортувальних гірок та
скорегувати параметри їх керування.

\section{Список літератури}

1. Образцов, В.Н. Основные данные для проектирования железнодорожных станций [Текст] / В.Н. Образцов. - М. : Государственное издательство, 1929. - 344 с.

2. Нагорный, Е.В. Научные основы и разработка комплексной технологии поточной и непрерывной переработки вагонов на сортировочных станциях [Текст] : автореф. дис. ... д-ра техн. наук: 05.22.08 / Е.В. Нагорный. - Харьков, 1994. - 54 с.

3. Берестов, И.В. Оптимизация параметров систем регулирования скорости движения отцепов на путях сортировочных парков [Текст] : автореф. дис. ... канд. техн. наук: 05.22.08 / И.В. Берестов. - Л., 1988. - 24 с.

4. Автоматизация и механизация переработки вагонов на станциях [Текст] / Ю.А. Муха, И.В. Харланович, В.П. Шейкин и др. - М.: Транспорт, 1985. - 248 с.

5. Иванченко, В.И. Новый подход к управлению процессом роспуска составов на сортировочной горке [Текст] / В.И. Иванченко, Н.Н. Лябах, А.А. Сепетый // Труды РИИЖТа. - Ростов-на-Дону, 1984. - С. 34-41.

6. Лебединская, Е.Н. Математическая модель программы роспуска составов с сортировочной горки [Текст] / Е.Н. Лебединская, Е.Г. Шепилова // Междунар. сб. научн. тр. - Ростов-на-Дону: РГУПС, 1998. - С. 31-37.

7. Шелухин, В. И. Универсальный модуль управления тормозными позициями [Текст] / В.И. Шелухин, И.Н. Малышев // Автоматика, связь, информатика. - 2000. - № 5. - С. 12-14.

8. Оптимизация режимов торможения отцепов на сортировочных горках [Текст]: монография / В.И. Бобровский, Д.Н. Козаченко, Н.П. Божко и др. - Днепропетровск: Изд-во Маковецкий, 2010. - 260 с.

9. Ахвердиев, К.С. Оптимальный горочный профиль и динамика скатывания отцепа по нему [Текст] / К.С. Ахвердиев, Б.И. Алибеков, В.П. Жуков // Транспорт: наука, техника, управление. - 1991. - № 8. - С. 13-18.

10. Жуковицкий, И.В. Управление замедлителями тормозной позиции сортировочной горки. Часть 1. Модель системы [Текст] / И.В. Жуковицкий, Г.И. Загарий, Н.И. Луханин // Информационно-управляющие системы на железнодорожном транспорте. - 2000. - № 5. C. 10-15.

11. Жуковицкий, И.В. Управление замедлителями тормозной позиции сортировочной горки. Часть 2. Модель системы [Текст] / И.В. Жуковицкий // Информационно-управляющие системы на железнодорожном транспорте. - 2002. - № 4. - С. 17-20.

12. Бобровский, В.И. Теоретические основы совершенствования конструкции и технологии работы железнодорожных станций: дис. ... д-ра техн. наук: 05.22.20 / В.И. Бобровский. - Днепропетровск, 2002. - 534 с. 
13. Шабельников, А.Н. Разработка теории и методов автоматизации управления сложными процессами на сортировочной станции [Текст]: дис. ... д-ра техн. наук: 05.13.06 / А.Н. Шабельников. - М., 2005. - 344 с.

14. Бессоненко, С.А. Теория расчета сортировочных горок для различных климатических зон [Текст]: дис. ... д-ра техн. наук: 05.22.08 / С.А. Бессоненко. - М., 2010. $411 \mathrm{c}$.

15. Правдин, Н.В. Расчет параметров сортировочной горки с учетом случайных ходовых свойств отцепов [Текст]/ Н.В. Правдин, С.А. Бессоненко // Транспорт: наука, техника, управление. - 2007. - № 7. - С. 8-15.

16. Общая теория систем [Текст]/ А.М. Иванов, В.П. Петров, И.С. Сидоров, К.А. Козлов. - С.Пб.: Научная мысль, 2005. - 480 с.

Ключові слова: сортувальна гірка, конструктивно-технологічні параметри, системний підхід, модель функціонування.

\section{Анотації}

Проаналізовано діючий науковий підхід до комплексного розрахунку і проектування висоти та поздовжнього профілю сортувальних гірок. Обгрунтовано необхідність застосування системного підходу до розрахунку раціональних конструктивно-технологічних параметрів. Наведено модель розрахунку вказаних параметрів.

Проанализирован действующий научный подход к комплексному расчету и проектированию высоты и продольного профиля сортировочных горок. Обоснована необходимость применения системного подхода к расчету рациональных конструктивнотехнологических параметров. Приведена модель расчета указанных параметров.

Operating scientific approach to the complex calculation and planning of sorting humps height and longitudinal type is analysed. The necessity of application of systems approach to calculation of rational structural-technological parameters is grounded. The model of the indicated parameters calculation is resulted. 